\title{
Historia a través de la fotografía El análisis de tarjetas postales de desnudo femenino de la Compañía Industrial Fotográfica
}

Aura Mariana Medina Hernández

Investigadora independiente

History Through Photography. An Analysis of Compañía Industrial Fotográfica's Female Nude Postcards

Recepción: 31 de enero de 2020

Aceptación: 11 de junio de 2020 


\begin{abstract}
Resumen
Las representaciones del desnudo femenino han sido una temática vigente prácticamente a lo largo de toda la Historia del Arte; sin embargo, fue hasta finales del siglo xIx que, con el perfeccionamiento de las técnicas y tecnologías fotográficas asistimos a un fenómeno de masificación de la imagen que posibilitó la circulación del cuerpo femenino desnudo a través de las tarjetas postales fotográficas. En el caso de México, un ejemplo claro de este fenómeno fueron las tarjetas postales de desnudos femeninos que produjo la Compañía Industrial Fotográfica alrededor de 1920, las cuales no sólo apostaron por la producción industrializada de imágenes, sino también por un juego iconográfico que se debatió entre un imaginario del arte legítimo y la censura moral de la época.
\end{abstract}

\title{
Palabras clave
}

Tarjeta postal, desnudo femenino, legitimación, circulación masiva

\begin{abstract}
Representations of the female nude have been a theme that prevails practically throughout Art History; however, it was not until the end of the $19^{\text {th }}$-Century, with the improvement of photographic techniques and technologies, when we witnessed a phenomenon of massification of the image that enabled the circulation of the female nude through photo postcards. In the case of Mexico, a clear example of this phenomenon were the postcards of female nudes that the Compañía Industrial Fotográfica produced around 1920 , which not only bet on the industrialized production of images, but also on an iconographic game that oscillated between an imaginary of legitimate art and the moral censorship of the time.
\end{abstract}

\section{Key words}

Postcard, female nude, legitimation, mass circulation 
Una tarde cualquiera de 1928 un amigo de Alfonso Nagore le mostró una fotografía de desnudo artístico, seguramente una más de aquellas postales que circulaban entre las calles de la Ciudad de México en aquella década. Hasta ese momento, el cuerpo desnudo que yacía en la imagen, con pose artística, carecía de rostro e identidad; sin embargo, a los ojos de Alfonso había algo de familiar en esa silueta, en los detalles de aquel cuerpo. Se trataba de su esposa: la mujer que hacía seis años había conocido a la salida de la escuela Miguel Lerdo de Tejada y que ahora, tal vez, formaba parte de una de tantas imágenes que llenaban los álbumes de coleccionistas.

Aquel encuentro con el desnudo de Sara Perea terminó en un crimen de honor que tomó por presa al fotógrafo Gustavo Galindo y a su modelo, la esposa de Alfonso. El periódico El Universal no dudó en cubrir la nota entre las páginas del 6 y 7 de marzo de 1928, pues Alfonso Nagore había sido exculpado por el jurado popular bajo el argumento de haber defendido el honor masculino, ya que durante el proceso su defensor exclamó: "iSi no hubiera usted matado, no sería hombre!"

Por otro lado, aunado a la favorable defensa de la dignidad masculina, se presentó otro argumento concerniente a la imagen en cuestión, donde Federico Sodi, el defensor señaló:

Si don Francisco de Goya y Lucientes retrata a la mujer de Nagore, desnuda, [...] el mundo del arte gana una gloria, pero el marido se gana una vergüenza. La exhibición de desnudos es lícita, legítima en las celebridades del cine o el teatro, o en las horizontales, gentes que viven en casa de cristal en lo que se refiere al físico, pero no para quien guarda el pudor, porque así lo exige la razón de los demás. ${ }^{1}$

1 Tanto la historia de Sara Perea como la cita fueron tomadas de: Aurelio de los Reyes, "Crimen y castigo: la disfunción social en el México posrevolucionario", 314. 
El caso del asesinato del fotógrafo Galindo y de Sara Perea proporciona una ventana para el análisis de las fotografías de desnudo femenino de los años veinte y la recepción de estas imágenes en la cultura visual mexicana. Los cuestionamientos en torno a estas imágenes son variados: podríamos preguntarnos quiénes producían y consumían esas fotografías, quiénes eran esas mujeres; ¿eran legales esas imágenes o formaban parte de un mercado ilícito?, ¿qué impacto tuvieron en los espectadores?

Como podemos observar, los temas que atraviesan las fotografías de desnudo femenino de principios del siglo xx son vastos, por lo cual uno de los propósitos del presente artículo consiste en proponer un análisis y una interpretación de las tarjetas postales de desnudo femenino como fenómeno de la cultura visual mexicana, acotando el estudio al trabajo que se llevó en el interior de la Compañía Industrial Fotográfica (CIF), 1915-1940.

Aquella fotografía que llegó a las manos del esposo de Sara Perea no era una imagen atípica; por el contrario, mostraba simplemente una práctica común entre los consumidores de tarjetas postales de la época, hecho que se puede constatar al menos con la producción de postales que realizaban algunos estudios fotográficos y compañías de mayor alcance.

Estamos frente a una fuente primaria que abre brecha en dos sentidos: por un lado, se convierte en una de tantas piezas de la historia de la fotografía, pues la tarjeta postal fotográfica ejemplifica una parte del desarrollo científico y técnico de este medio de comunicación y expresión; por el otro, otorga la posibilidad de hacer historia a través de la fotografía, en cuanto que funge como medio de conocimiento visual del pasado para comprender las formas de representación del cuerpo femenino y sus implicaciones. $^{2}$

2 Boris Kossoy, Lo efímero y lo perpetuo, 57. 


\section{TARJETA NACIONAL ANUNCIADORA}

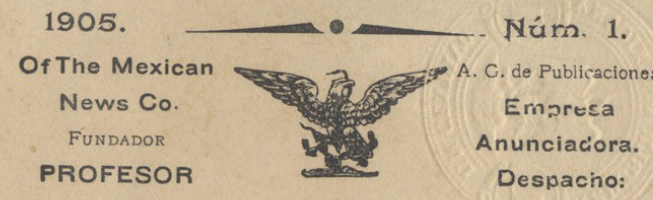

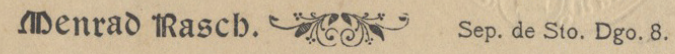

消 MEXICO D. F. 将

-Especialidad-

TARJETAS ILUSTRADAS CON FELICI-

TACIONES DE AÑO NUEVO (1906.).

- PRECIOS

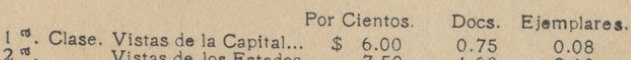

$\begin{array}{lllll}1 \text { \%. Clase. Vistas de la Capital... } & \$ 6.00 & 0.75 & 0.08 \\ 2 \pi & & \\ 3 \text { \%. Vistas de los Estados. } & 7.50 & 1.00 & 8.10\end{array}$

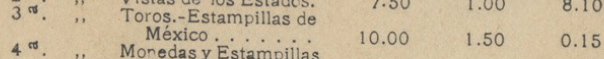

$\begin{array}{lllll}4 \text { ". . Monedas y Estampilias } & & & & \\ \text { de varios Países. . } & 12.50 & 2.00 & 0.20\end{array}$

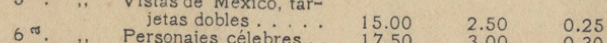

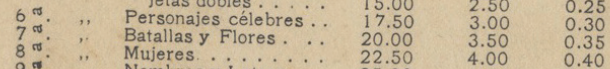

$\begin{array}{llll}90^{\circ} & \text { N... Nombres y Letras. . . } & 25.00 & 4.50 \\ 10 & \text { Pintadas a mano. . . } & 30.00 & 5.45 \\ \end{array}$

Nota 1 \%. A los pedidos de fuera, se recargan los gastos de remisión

se remitirá, si lo soliciten, un surtido completo por

2 . Las tarjetas postales ilustradas se pueden adquirir, rebajando

un $25 \mathrm{p} 8$. de los precios arriba estipulados.

Nos encargamos de remitir tarjetas de felicitación en blanco
ó impresiones,

ó con impresiones, sin ó con sobres.

a A PRECIOS SIN COMPETENCIA (सख? sean corrientes ó de gusto exquisito y lujo extraordinario. Nuestro Lema:

BARATURA, ARTE Y PRONTITUD.

Figura 1. Tarjeta Nacional Anunciadora, Fototeca Manuel Toussaint. Instituto de Investigaciones Estéticas-UnAM.
La historia de las postales se remonta a finales del siglo xIX en Austria; ${ }^{3}$ la idea se atribuye a Heinrich von Stephany (1831-1897) ${ }^{4}$ y Emmanuel Hermann (1839- 1902), ${ }^{5}$ quienes en 1869 hicieron posible la aparición de este producto como un objeto comercial capaz de abaratar los costos del servicio postal. ${ }^{6}$ Un año después se introdujo el uso de las postales en el sistema de correo de países como Alemania, Suiza e Inglaterra, mientras que a España llegó hasta $1873 .{ }^{7}$ Para el caso mexicano fue en 1879 cuando, en la Convención de París, Gabino Barreda (1818-1881) ${ }^{8}$ firmó los convenios de la Unión Postal Universal para la unificación de los criterios postales. $^{9}$

La principal característica de las tarjetas postales radica en sus pequeñas dimensiones, su capacidad para enviar mensajes rápidos y concretos; elementos de los que carecían las cartas de la época, por ello resultaba más fácil y económico el envío de estos pequeños trozos de cartón que de alguna manera correspondían a los procesos de aceleración de un tiempo enmarcado en la Segunda Revolución Industrial y que no tenían la misma confidencialidad de la carta en sobre. Esta falta de confidencialidad es muy importante porque exalta una dinámica de vouyerismo y exhibicionismo, pues la postal en su trayecto pasa por diversas personas, develando así su contenido escrito e iconográfico.

3 Francisco Palá Laguna, "La tarjeta postal ilustrada", 33.

4 Heinrich von Stephany fue director general de correos del imperio alemán y organizador del sistema postal alemán.

5 Emmanuel Hermann fue un economista nacional austriaco que se involucró en la invención de la tarjeta postal.

6 Mariana López Hurtado, La tarjeta postal como documento, 21.

7 Palá, "La tarjeta postal ilustrada", 33.

8 Médico, filósofo y político mexicano que ese año (1879) fue ministro en funciones diplomáticas en Alemania.

9 Alejandra Osorio Olave y Felipe Victoriano Serrano, Postales del Centenario, 25. 
Un elemento importante para la popularización de las tarjetas postales ilustradas durante el siglo $x x$ fueron las técnicas fotográficas empleadas, tales como: heliotipia, ${ }^{10}$ fotolitografía, ${ }^{11}$ colografía y fototipia, ${ }^{12}$ las cuales hicieron posible la reproducción de postales en papel en blanco y negro, o sepia; a veces también se coloreaban a mano. El desarrollo y aplicación de dichas técnicas favorecía el consumo del producto porque resultaba innovador para su público, pero también porque favorecía un ideal de modernización y vanguardia, el producto no sólo resultaba agradable a la vista, era funcional y barato, respondía a la inmediatez de una época moderna, un momento de transición de modelos tradicionales hacia otros modernos, así como la transformación de industrias que se sumaban a la dinámica capitalista.

Por otro lado, las fotografías disminuyeron sus costos y el público consumidor se diversificó incluso hacia la clase media-baja, al menos entre los costos de las postales podemos ver que éstos variaban según el tema y la técnica, como se aprecia en la postal anunciadora (fig. 1).

10 La heliotipia, conocida también como colotipia, es un procedimiento de impresión planográfico, fotomecánico que utiliza una placa sensibilizada de gelatina para realizar una impresión de tono continuo. Puede hacer reproducciones excelentes de ilustraciones, pero solamente sirve para periodos cortos. Para una definición más amplia del proceso puede consultarse F. J. M. Wijnekus y E. F. PH. Wijnekus, Dictionary of the Printing and Allied Industries: In English, French, German, Dutch, Spanish and Italian, 137.

11 Fotolitografía: proceso en el que se emplea la fotografía para la producción de la imagen en una superficie de impresión final. La superficie de impresión original, piedra litográfica, ha sido desplazada casi por completo por láminas de metal delgadas y flexibles (aluminio, zinc, acero inoxidable, planchas bimetálicas y polimetálicas). El procedimiento fotolitográfico más antiguo fue el proceso de albúmina en el que las imágenes captadas con luz y entintadas con albúmina bicromatada sirvieron como superficie de impresión real. Para consultar la definición en su idioma original, véase Wijnekus, Dictionary of the Printing, 444.

12 Fototipia: proceso de impresión de fotografías en tinta descubierto por el francés J. Joubert en 1860 y mejorado por Tessiè en la década de 1870. Su aplicación más común fue la impresión de postales y consistía en aplicar una capa de gelatina bicromatada sensibilizada con sales de cromo sobre un cristal. Esta placa era impresa mediante un negativo fotográfico y la luz endurecía la gelatina creando una plancha de impresión por tinta. El formato universal de la postal es de $9 \times 14 \mathrm{~cm}$ y su periodo de apogeo fue entre 1891 y 1915, momento en el que la fototipia comenzó a ser sustituida por el papel fotográfico". Cita tomada de Antonio Jesús González y Eva María Delgado Sánchez, Postales andaluzas. Rafael Señan y la fotografía turística (1864-1911), 49. 


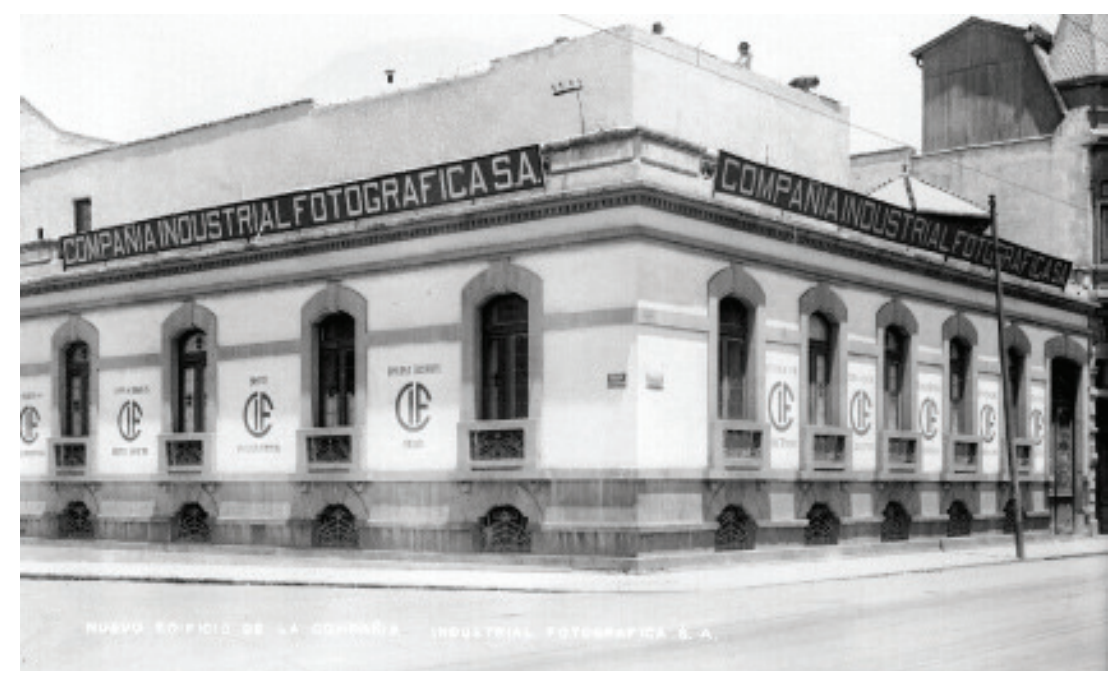

Figura 2. Compañía Industrial Fotográfica. Placa seca de gelatina, 12.7 × $17.8 \mathrm{~cm}$. Ciudad de México, ca. 1920, Fototeca Nacional. Reproducción autorizada por el Instituto Nacional de Antropología e Historia.

Gracias a esta fuente, se estableció un rango aproximado de costos de las postales: éstas se vendían por cientos que van de los $\$ 6$ a los $\$ 30$, por docena de los 0.75 centavos a los $\$ 5$, y por ejemplar de 0.08 centavos a los 0.50 centavos. En este rango de precios, las más baratas corresponden a las Vistas de la Capital, mientras que el precio más alto está impuesto a las postales pintadas a mano. Como se puede apreciar, las temáticas son variadas debido a que "sean corrientes ó de gustos exquisito y lujo extraordinario. Nuestro Lema: Baratura, Arte y Prontitud”. Así, las postales fueron pensadas como producto de consumo de masas, el cual se diversificó en gustos, géneros y precios, al mismo tiempo que respondió a una demanda considerable de tiempos inmediatos.

Se presenta una diferencia sustancial en la relación de precios y temas, las postales más caras corresponden a la técnica manual, como es el caso de las pintadas a mano, mientras que las demás responden a la temática. En el caso de "Nombres y Letras" posiblemente se deba a los trámites que implica la reproducción de piezas musicales, o al trabajo en la búsqueda de tipografías especiales; mientras que para el caso de "Mujeres", si bien 
no se especifica qué tipo de mujeres se están representando, posiblemente se trate de actrices, bailarinas, vedettes o desnudos femeninos, lo cual implicaba también costos que sobrepasan una producción de postales comunes como fue el caso de Vistas de la Capital o imágenes de toros.

El caso de las postales que dedicaron su mirada al tema femenino nos presenta una problemática interesante; se trata de la masificación de representaciones del desnudo y su circulación por diferentes espacios y estratos socioeconómicos. Por medio de estas imágenes se pone al alcance de la población una serie de modelos o estereotipos de belleza femenina inalcanzables, que sólo podrán estar en poder de quienes adquieran, compren o coleccionen tales imágenes; ésa es precisamente la innovación de este tipo de postales: que son de fácil adquisición para muchas personas.

Se debe aclarar que a pesar de que existieron imágenes con escenas sexuales totalmente explícitas, las más comunes y aquellas que gozaron de libertad de circulación e imprenta fueron las que aludieron a un sentido artístico, producto de la tradición academicista en el arte. Pues como bien señala Ava Vargas "la fotografía de desnudo prácticamente se dividía en imágenes pornográficas explícitas y poses clásicas al estilo europeo, cubiertas con velos y ropajes para denotar que tanto el fotógrafo como el espectador tenían aspiraciones más elevadas". ${ }^{13}$

En el escenario mexicano de la posrevolución se presentaron postales fotográficas de todo tipo, desde las que atendieron las demandas de la reconstrucción nacional, la búsqueda de raíces indígenas y las modas exportadas desde el extranjero, hasta las series fotográficas de artistas de teatro y cine - un producto que también empezaba a masificarse-. Estas fotografías enarbolaban la moda de las flappers y las tiples de la década de los años veinte. Sus imágenes se produjeron masivamente gracias al formato de la tarjeta postal, de tal manera que este soporte permitía transportarlas o enviarlas fácilmente a cualquier lugar e incluso coleccionarlas en álbumes.

13 Ava Vargas, La casa de citas en el barrio galante, XIX. 
La práctica del coleccionismo fue muy común en lo que respecta a la producción fotográfica. Esta actividad se manifestó desde la conservación de álbumes familiares y posteriormente con el fenómeno de la tarjeta postal.

La práctica del coleccionismo enfatiza la necesidad de poseer imágenes de lo propio y lo que nos rodea, el mundo hecho objeto susceptible a la cosificación y posesión. Las fotografías de figuras femeninas que circularon en las primeras décadas del siglo xx no sólo permitieron la reproducción de la imagen de mujeres famosas y atractivas, sino también la posesión de éstas, tanto visual como materialmente, en una postal, de tal manera que el consumidor del producto poseía entre sus manos aquellas figuras femeninas inalcanzables, transgresoras por las modas que imponían y por la manera en que utilizaban su cuerpo para seducir y atraer a las masas de espectáculos que se llevaban a cabo en teatros y cines. Así, las postales fotográficas femeninas generaron en el consumidor la sensación de posesión y cercanía a los cuerpos de estas mujeres tan deseadas; de ahí también su éxito en el mercado.

Entre los productores de representaciones femeninas en el formato postal, destaca la CIF (1915-1940) ${ }^{14}$ (fig. 2), quien identificaba sus imágenes con un registro de propiedad artística y una numeración que correspondía al número de postal realizada (fig. 3). Los datos ubicados en la esquina superior derecha de la postal constatan la existencia de la empresa y su producción masiva de imágenes, la cual, además, se interesó por registrar sus fotografías como propiedad artística, como un medio para asegurar la autoría sobre el producto y el derecho único a lucrar con él.

La CIF estuvo conformada por diferentes fotógrafos residentes en la Ciudad de México, aunque no se puede asegurar con certeza que la nacionalidad de éstos fuera mexicana. La empresa ubicada en la calle de Motolinía número $2,{ }^{15}$ fue una nueva industria en el país dedicada principalmente a la venta de postales y fotografías baratas. ${ }^{16}$ La producción y reproducción de

14 Monterrey en 400 fotografías, 233.

15 Diario Oficial de la Federación, 14 de julio de 1922, t. xxI, número 63.

16 Instrucción Pública y Bellas Artes, caja 24, exp. 31, 1918. 


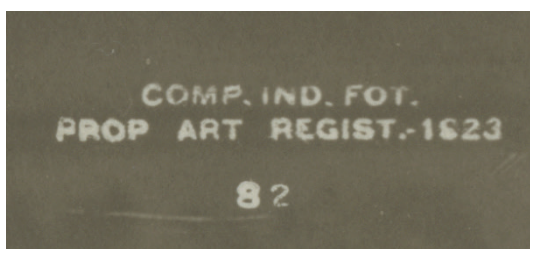

Figura 3.Compañía Industrial Fotográfica Mujer posando. Tarjeta postal.

Ciudad de México, 1924. Archivo General de la Nación, Fondo Instrucción Pública y Bellas Artes, Serie Propiedad Artística y Literaria, número de inventario 33.

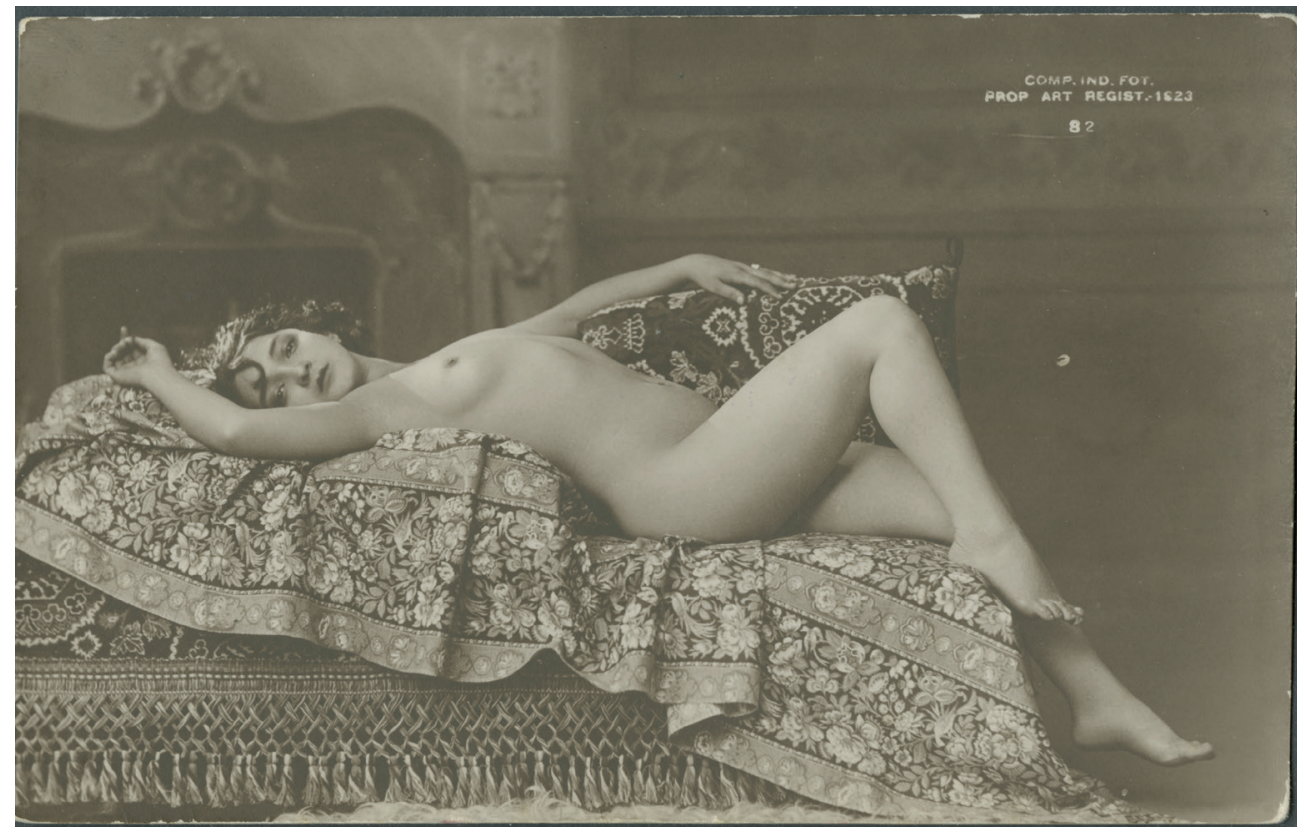

estas tarjetas captaron imágenes de paisajes y vistas de ciudades de la República Mexicana; retratos de artistas,${ }^{17}$ desnudos, escenas costumbristas, tipos mexicanos y reproducciones de obras de arte.

Es escasa la información acerca de los socios de la CIF; hasta ahora la figura que aparece con mayor frecuencia en las fuentes es la de Francisco Lavillette, un fotógrafo francés nacido en $1863^{18}$ que vivía en la Ciudad de México, quien se movía entre los círculos de la cinematografía y la fotografía, pues produjo argumentos y comedias cinematográficas ${ }^{19}$, así como inventos que favorecieron el desarrollo de la producción fotográfica mexicana. ${ }^{20}$

17 Artistas como las Hermanas Tellez Wood, Chole Álvarez Mimi Derba, María Conesa, Lupe Rivas Cacho, Celia Montalván, Amelia Wilhelmy, María Tubau, Rosa Fuertes, Celia Padilla, Laura Marín, Margarita Carbajal, Celia Cedeño y Emma Cedeño, entre otras. Por otra parte, también hay que mencionar que la CIF contó con el registro y la propiedad artística de estas colecciones. Véase Diario Oficial de la Federación, 14 de julio de 1922.

18 AGN, Tribunal Superior de Justicia del Distrito Federal, siglo xx, Archivo histórico I, 1928, caja 2204, folio 402833, f. 6.

19 Se tienen registros de dos producciones cinematográficas en 1919 a nombre de Francisco Lavillette: Dos corazones y Jugar con fuego, así como su producción musical para este medio en 1927 con la composición En mis brazos. Véase "Producción artística y literaria".

20 Francisco Lavillette también patentó algunos inventos, como un aparato para imprimir con una sola exposición en una misma hoja de papel fotográfico o un sistema para recortar en morina de bisel los contornos de cualquier fotografía, imagen o grabado que estuvieran adheridos a un material rígido. Véase Secretaría de Comercio y Fomento Industrial, Patentes y Marcas, leg. 196, exps. 23 y 71. 
Nierika 20 - Año 10 - julio-diciembre de 2021

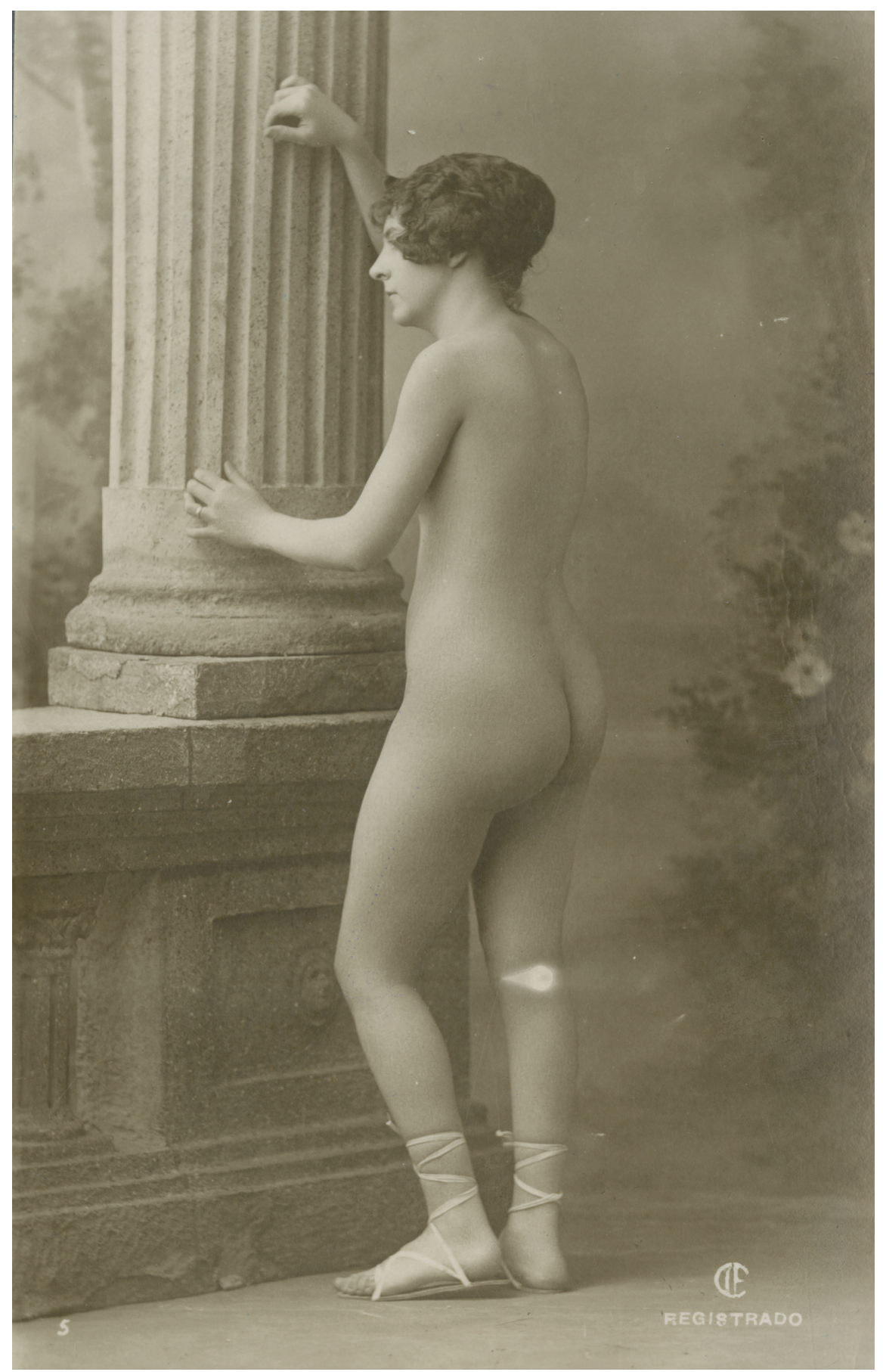

Figura 4. Compañía Industrial Fotográfica. Mujer posando. Tarjeta Postal.

Ciudad de México, 1924, Archivo General de la Nación, Fondo Instrucción Pública y Bellas Artes, Serie Propiedad Artística y Literaria, número de inventario 3. 
En cuanto a los fotógrafos de la Compañía, hasta ahora no se ha encontrado ningún documento que muestre su identidad, puesto que los registros de la fotografía frente a la Secretaría de Educación Pública (SEP), se hicieron simplemente a título de la CIF y el único nombre que se hace presente es el del gerente de la misma, Lavillette. ${ }^{21}$ Sin embargo, vale la pena ahondar en la trayectoria de este fotógrafo, pues su tendencia pictorialista pudo ejercer una importante influencia en la producción de tarjetas postales de desnudo femenino.

El trabajo de Lavillette se legitimó en los "largos años de práctica en los primeros talleres de Francia", ${ }^{22}$ así como su experiencia trabajando al lado de fotógrafos reconocidos como Felipe Torres ${ }^{23}$ o Emilio Lange en México. ${ }^{24}$

21 Este procedimiento no se llevó a cabo de la misma manera con la compra de canciones o piezas musicales, pues en estos registros sí se enfatiza el nombre del autor. Con esto podemos ver que la cuestión de los autores dentro del mundo de la fotografía cuenta con ciertas dificultades, primero que nada por la naturaleza de la fotografía, su facilidad para ser reproducida por diferentes medios hizo en muchas ocasiones casi imposible la atribución a un autor de obra; por otra parte, el medio en el que se realiza, pues en el caso de la CIF no hay un reconocimiento al trabajo individual de sus fotógrafos; sin embargo, en algunos otros casos los negocios de postales estuvieron al mando de un fotógrafo, único autor de las imágenes, como ocurrió con Hugo Breheme.

22 El Correo Español, 31 de diciembre de 1902, 3.

23 La figura de Felipe Torres fue importante en la historia de la fotografía mexicana, principalmente por el éxito y reconocimiento que ganaron las fotografías del estudio "Hermanos Torres", donde Felipe trabajaba con su hermano Manuel. Ambos habían aprendido el arte de la fotografía en distintos estudios europeos a finales del siglo XIX, y sus fotografías habían sido premiadas con medalla de plata en la Exposición Universal de París (1900). En México formaron parte de la Sociedad Fotográfica Mexicana, participaron en los concursos de esta asociación, así como en las convocatorias emitidas por las revistas ilustradas de la época y sus fotografías alcanzaron el reconocimiento y premiación debido a su técnica y estilos, entre los que destaca el pictorialismo. El contacto de Felipe Torres y Francisco Lavillette se llevó a cabo en el estudio de fotografía francesa ubicado en la calle del Espíritu Santo número 7, en donde Lavillette realizaba algunos de los retratos de estudio. La información que proporciona la prensa de este periodo no permite saber con exactitud cuántos años trabajaron juntos; sin embargo, este encuentro pudo haber influido en el estilo y producción fotográfica de ambos, especialmente en lo que corresponde a la producción pictorialista de Lavillette.

24 Por su parte, la relación de Emilio Lange y Francisco Lavillette se estableció en términos muy diferentes. Emilio Lange era un fotógrafo sueco que vivía en México y al igual que los "Hermanos Torres" gozaba de un reconocimiento significativo; había sido premiado en exposiciones como la Exposición Colombina en Chicago (1893) y la Exposición Universal del París (1900). Este fotógrafo contaba con una galería, junto a las más 
En la producción fotográfica de postales de desnudo femenino de la CIF se puede apreciar en la técnica pictorialista una posible influencia del bagaje cultural europeo de Lavillette, así como de sus contemporáneos. El pictorialismo se caracterizó por la difuminación de fondos y la recurrencia al pasado como un elemento de distanciamiento temporal capaz de generar la ilusión de estar en otros espacios ajenos al propio. En el caso de las postales que se analizan en este trabajo, el distanciamiento temporal y espacial presenta una fuerte influencia de la pintura europea decimonónica, especialmente la de corte neoclásico y orientalista, sin mencionar que muchas de las postales tienen similitudes con otras provenientes de España y Francia. ${ }^{25}$

El sentido pictorialista que se percibe en las postales de la CIF a cargo de Lavillette, se caracteriza por una producción afín a la primera generación del pictorialismo en México; es decir, el proceso en el cual "el discurso fotográfico fue convocando a las artes 'mayores', apropiándose de sus preceptos, para catapultarse hacia un escenario inesperado". ${ }^{26}$ Es por ello que las imágenes que se analizarán en este trabajo hacen referencia, principalmente, a un bagaje cultural situado en las artes europeas como la representación de espacios íntimos afrancesados o burgueses, las figuras estilizadas de la escultura griega y el exotismo de Oriente.

prestigiosas, en la calle de San Francisco de la Ciudad de México y también había sido premiado en algunos concursos nacionales, como fue el caso del Concurso de Arte y Belleza de El Mundo Ilustrado (1905), donde fue premiado en primer lugar su estudio de cabeza de la señorita Luisa Gordillo, un retrato de corte pictorialista que apareció en la portada de la revista. En los años previos a 1902 Lange estuvo a cargo de la dirección del estudio fotográfico de Carlos Hirschberg; ahí realizó principalmente retratos y posteriormente se independizó abriendo su propio estudio. El puesto fue tomado por Francisco Lavillette quien retomó la labor del retrato y realizó impresiones fotográficas de tomas anteriormente hechas por Lange. De esta forma, Lavillette estuvo en contacto directo con el trabajo de Lange, además del reconocimiento y publicación constante de sus fotografías en la prensa de principios del siglo xx, ambos elementos fueron posibles contribuciones al trabajo del gerente de la CIF.

25 Para profundizar en las similitudes existentes entre las postales de desnudo femenino de la CIF y las europeas, véanse: Christian Bourdan, Jean Agélou. De l'académisme à la photographie de charme; Hammond Paul, French Undressing: Naughty Postacrds from 1900 to 1920; Maite Zubiaurre, Culturas del erotismo en España 1898-1939.

26 Carlos A. Córdova, Tríptico de sombras, 16. 
Otro aspecto destacable en la trayectoria de este fotógrafo es su constante interés por el mercado de la fotografía, pues sus anuncios se caracterizaron por enfatizar la vanguardia tecnológica y la eficacia del producto, retratos y reproducción de imágenes en reducidos tiempos y de buena calidad. En este sentido, la tarjeta postal desempeñó un papel muy importante, pues se convirtió en un producto de amplia circulación; muchas de las imágenes que Lavillette registró antes de llegar a ser gerente de la CIF estuvieron pensadas para su venta como postales; es por ello que este fotógrafo tenía amplio conocimiento de cómo funcionaba este mercado y de la importancia de poseer los derechos de la imagen para su exclusiva reproducción, elementos muy presentes en la manera en que funcionó la producción de tarjetas postales de la ClF.

Si bien es cierto que la temática del desnudo tiene su origen y consagración en el campo de la pintura y la escultura, fue gracias a la fotografía y la tarjeta postal que la temática se masificó y llegó al alcance de un público antes ignorado. No obstante, se debe poner atención en los mecanismos comerciales utilizados para llevar a cabo esta labor, pues desde los inicios de la fotografía hay registros de daguerrotipos y otras técnicas que representaron el desnudo femenino, ${ }^{27}$ pero siempre en un espacio relegado y prohibido, pues dichas imágenes fueron consideradas transgresoras e inmorales; la diferencia entre los desnudos ocultos y los masificados radica principalmente en su producción y en cómo se hicieron públicos.

Entonces, ¿cuáles fueron los recursos empleados en empresas como la CIF para poder producir y vender postales de desnudo? Un medio para llevar a cabo esas representaciones fue el pictorialismo ${ }^{28}$ (fig.4). El pictorialis-

27 Para una muestra de estas imágenes, véase Jashca Kempe, 100 Nudes. A History of Erotic Photography from 1839-1939.

28 En lo que respecta a las palabras pictorialista y pictorialismo se debe aclarar que a pesar de ser conceptos empleados en la historia y crítica del arte, no aparecen en los diccionarios de la lengua castellana, pues que son una apropiación del inglés. Como bien aclaran algunos investigadores sobre la historia de la fotografía: "Los orígenes de la palabra pictorialismo confirman la naturaleza de su proyecto. El término deriva de la expresión inglesa pictorial photography, en la que pictorial es un calificativo que provie- 
mo fue una de las respuestas ante la discusión que puso en duda el lugar de la fotografía como arte o como mera técnica, se planteó así una fuerte relación entre pintura y fotografía, en donde se retomaron los aspectos formales y códigos simbólicos de la pintura. De esta forma se dotó a las postales de cierto sentido artístico ${ }^{29}$ que aminoró la irrupción del desnudo en el espacio público y posibilitó así su circulación en el mercado nacional e internacional.

Entre las postales recuperadas del AGN se identificaron tres temáticas: el mundo clásico, la vida cotidiana en el espacio privado y la influencia del orientalismo. Estos temas tienen puntos de encuentro con el arte academicista del siglo xIX, el cual ya se había consolidado como uno de los modelos institucionales fundamentales que establecieron un sentido del buen gus$t^{30}$ entre las clases medias y altas, el cual fue rescatado como una herramienta de mercado que permitiera la venta de este tipo de postales, pues eludía las legislaciones que censuraban otro tipo de desnudos considerados inmorales o pornográficos.

Para acotar un concepto tan problemático como el sentido de buen gusto, se tomará la propuesta de Pierre Bourdieu, quien establece una clasifica-

ne de la palabra picture, que significa 'imagen' o 'cuadro', y no pintura, que la lengua inglesa traduce como painting. [...] La presencia de la palabra picture en la denominación inglesa del movimiento recuerda cuál fue su objetivo inicial: dar a conocer la fotografía como una imagen entre las demás imágenes". Cita tomada de Marc Mélon, "Más allá de lo real: La fotografía artística", 87.

29 El pictorialismo no gozó de una aceptación completa; por el contrario, abrió un debate aguerrido entre fotógrafos, teóricos y artistas. Algunas de estas opiniones pueden ser consultadas en Joan Fontcuberta (ed.), Estética fotográfica.

30 El gusto se puede relacionar con diferentes aspectos humanos, desde el sentido corporal con el que se perciben los alimentos, hasta cuestiones culturales más complejas en donde entran en juego las construcciones sociales de las clases hegemónicas de lo bello o lo feo. En este sentido, al hablar del gusto o buen gusto, la intención es referirme a una construcción social de dichas categorías, en donde ciertos objetos valorados en las clases económicas altas se consideran como estéticamente placenteros, pertenecientes a esa esfera cultural aparentemente lejana de un público más general. 
ción del gusto en: el gusto legítimo, ${ }^{31}$ el gusto medio ${ }^{32}$ y el gusto popular. ${ }^{33}$ Es así que la definición del gusto legítimo resulta útil para comprender cómo es que la antigua Academia de San Carlos consolidó un ideal del gusto que se reconoció e implantó en otras formas de expresión, como fue el caso de la fotografía. En este sentido, se debe enfatizar que la generación de un gusto legítimo innegablemente está ligada a los centros de poder político, económico y artístico que establecen los lineamientos culturales de mayor peso. Esto quiere decir que:

toda obra legítima tiende en realidad a imponer las normas de su propia percepción, y que define tácitamente como único legítimo el modo de percepción que establece cierta disposición y cierta competencia; no es constituir en esencia un modo de percepción particular, sucumbiendo así a la ilusión que fundamenta el reconocimiento de la legitimidad artística, sino hacer constar el hecho de que todos los agentes, lo quieran o no, tengan o no tengan los medios para acomodarse a ello, se encuentran objetivamente medidos con estas normas. ${ }^{34}$

A pesar de que el gusto legítimo o buen gusto impone un referente de valor sobre el cual se mide o evalúa la producción de las obras, esto no omite por ningún motivo el proceso de distinción que se genera como una de las consecuencias inmediatas, puesto que se presenta una diferenciación rigurosa entre las diferentes clases con base en el consumo legítimo de obras legítimas.

31 Éste se inclina por las obras clásicas de la pintura o aquellas piezas musicales brillantes, elementos que conservan una relación con una posición elevada del nivel escolar o las clases dominantes más ricas en capital escolar.

32 Se refiere a las obras menores de las artes mayores, y las obras más importantes de las obras menores; estos gustos, como su nombre lo indica, son visibles con mayor frecuencia entre las clases medias o en las fracciones intelectuales de la clase dominante. 33 El gusto popular hace referencia a obras desvalorizadas por la divulgación, pero sobre todo por aquellas obras desprovistas de ambición o pretensiones artísticas; este gusto se encuentra frecuentemente entre las clases populares y varía en razón inversa al capital escolar.

34 Pierre Bourdieu, La distinción. Criterio y bases sociales del gusto, 33. 
En el caso de las postales en cuestión, el fenómeno radica principalmente en poner al alcance de grupos sociales más amplios una serie de desnudos artísticos que por sus medios de producción se venden a costos más accesibles que si se buscara comprar una pintura o escultura de la Escuela Nacional de Artes Plásticas. Es justamente este proceso el que nos interesa destacar, es decir, la transición del arte académico entendido como el gusto legítimo hacia su apropiación y reproducción en objetos de consumo que buscan fragmentar las barreras de la distinción como una estrategia fructífera para el mercado, en este caso la producción de tarjetas postales de desnudo femenino; pues, como bien apunta Lynda Nead:

\footnotetext{
Más que otro tema cualquiera, el desnudo femenino connota "El Arte". La imagen enmarcada de un cuerpo desnudo, colgada en la pared de una galería de arte, constituye normalmente una abreviación del arte; es un ícono de la cultura occidental, un símbolo de la civilización y el talento. ${ }^{35}$
}

Es así como el papel de las academias de arte tuvo una influencia significativa en otro tipo de imágenes que no necesariamente pertenecían a un círculo artístico determinado, pero que sí estaban influidas por un imaginario cultural de lo que las instituciones académicas habían designado como obras y temas de buen gusto. Pero ¿qué tenían de especial estas imágenes, además de ofrecer una visión erotizada de mujeres? Se trata de una estrategia de mercado en donde "un producto implantado en los círculos superiores de la sociedad se difunde a la lower middle class que aspira a los mismos productos, pero más baratos. En consecuencia, las grandes tiendas satisfarán esa demanda poniendo en venta el producto de reemplazo", ${ }^{36}$ como ocurrió justamente con las postales pictorialistas de la CIF, las cuales abarataron significativamente las representaciones del cuerpo femenino desnudo, utilizando como vehículo el lenguaje artístico legítimo.

35 Lynda Nead, El desnudo femenino: arte, obscenidad y sexualidad, 11.

36 Abraham Moles, El kitsch, el arte de la felicidad, 93. 
Este proceso de abaratamiento de un tema del gusto legítimo nos lleva precisamente al análisis de la forma, donde podemos encontrar que nuestro objeto de estudio mantiene ciertas características que se repiten constantemente. Se enfatizan tres aspectos fundamentales: el primero de ellos corresponde al estilo pictorialista; el segundo hace referencia a los cuerpos que han sido capturados por la lente del fotógrafo, mientras el tercero se enfoca en el carácter anónimo de los individuos que participan en la producción de estas postales.

En lo que corresponde al estilo, todas las imágenes son pictorialistas, por lo que predomina un difuminado de los fondos, los cuales en su mayoría están pintados en telones que forman parte de la escenografía. Por otra parte, estas fotografías cuentan con una fuerte influencia del arte pictórico y escultórico clásico, el cual se rastreó desde el Renacimiento hasta el siglo XIX en el caso de la pintura, mientras que la influencia escultórica se remitió al arte griego y romano.

En lo referente a los cuerpos femeninos que se representaron, hay que destacar que todas las modelos portaron la moda del cabello corto y ondulado tan en boga en la década de los veinte. ${ }^{37}$ A partir de 1924 en la Ciudad de México se adoptó el pelo corto y los cuerpos atléticos en las mujeres; esta tendencia de cabelleras causó gran revuelo a nivel mundial porque "cortarse el pelo de ese modo representaba una toma de partido por lo 'moderno' y una ruptura con la 'tradición' donde quiera que las mujeres lo intentaran”. ${ }^{38}$ En el mundo anglófono fueron llamadas flappers; ${ }^{39}$ sin embargo, en México se refirieron a ellas, en las calles, las revistas y periódicos, como "las pelonas". ${ }^{40}$

37 A lo largo de las primeras décadas del siglo xx mexicano se presentó la influencia de modas importadas principalmente de Estados Unidos, de donde hay una apropiación de los estilos del cabello, la ropa y el cuerpo femenino atlético.

38 Anne Rubenstein, "La guerra contra 'las pelonas', las mujeres modernas y sus enemigos, Ciudad de México, 1924", 92.

39 Se empleó este término porque se relacionaba con los vestidos cortos que utilizaban, los cuales daban la impresión de que "aleteaban" (flapped).

40 Las famosas pelonas de los años veinte causaron tanta conmoción en la Ciudad de México que fueron motivo de diversas notas y representaciones en la prensa, desde las críticas y burlas, hasta los reportes de los actos de violencia que en ocasiones las hicieron víctimas. 
El primer choque que se presentó ante esta moda radicó en la contraposición de lo "nacional" frente a las tendencias extranjeras, pues "en México, la abundancia capilar había enorgullecido siempre a las mujeres, y el pelo lacio heredado de la Malinche había acudido en el siglo xIx y principios del [siglo xx], a las domésticas pinzas calientes para rizarse. En consecuencia, las pelonas Ilamaron aquí más la atención que en otras naciones". ${ }^{41}$ Esto debido también a que la cabellera larga, además de aludir a un sentido nacional, se manifestó como un elemento de feminidad que caracterizaba al cuerpo hasta ese periodo.

En un momento crucial para la reconstrucción nacional ${ }^{42}$ y la búsqueda de una identidad mexicana, que se intentó encontrar en las raíces indígenas como un símbolo cultural del México auténtico, era de esperarse que la actitud frente a los modelos importados del extranjero fuera hostil, como lo fue con las mujeres que renunciaron al cabello largo. No obstante, las reacciones frente a las famosas pelonas mexicanas llegaron a un extremo de violencia, en el cual se llegó incluso a la agresión física contra ellas: estudiantes de la Escuela Preparatoria y de la Escuela de Medicina, llegaron a secuestrar a jóvenes estudiantes "cuasi-flappers" ${ }^{\prime 3}$ para raparlas e insultarlas. ${ }^{44}$

En cualquiera de los casos el corte de cabello representó una ruptura con el ideal que se había construido en torno a la feminidad y en muchos casos fue percibido como un signo transgresor, el cual coincide con algunas representaciones de la misma naturaleza, como el caso de las postales de ve-

41 Salvador Novo, Viajes y Ensayos I, 508.

42 Después de la Revolución Mexicana el país se enfrentó inevitablemente a un proceso de transformaciones políticas, económicas y culturales que atravesaron todas las esferas sociales, en busca de sentar las bases de un nuevo periodo de estabilidad. Este proceso de reconstrucción nacional también se hizo presente en el campo de las artes, a través de un movimiento pendular, señalado ya anteriormente por Jorge Alberto Manrique en el tomo iv de su Visión del arte y de la historia, en donde se evidenció la disputa entre lo nacional y lo extranjero, para generar una cultura visual que respondiera a las nuevas necesidades de la sociedad postrevolucionaria.

43 Término empleado para designar a las mujeres de apariencia mestiza u obreras que utilizaran la moda en boga del cabello corto.

44 El Universal Gráfico, 22 de julio de 1924. 
dettes y desnudos femeninos. La constante es la polémica que causa la presencia del cuerpo femenino en ciertos grupos sociales, ya sea por el corte de cabello o la desnudez "exagerada".

El problema se centra en cómo ciertas características físicas de las mujeres se relacionan con modelos morales, sexuales, de belleza o incluso de afinidad política, como se puede ver en torno a las noticias que se dieron a conocer de los atentados en contra de las pelonas. Estas mujeres, consideradas un modelo de modernización, no sólo habían roto los cánones tradicionales del cuerpo femenino y las connotaciones morales en torno a él; también mantenían una estrecha relación con las figuras de la farándula, especialmente del teatro, mujeres consideradas peligrosas para las buenas costumbres.

En este sentido, la época posrevolucionaria, en cuanto proceso coyuntural, dejó abierta la posibilidad de transformación; mediante la transición que se presentó en la segunda década del siglo xx, las mujeres tomaron la oportunidad del cambio para ejercer actos de liberación que se reflejaron en su organización y campos de acción. Pero estos mismos cambios posibilitaron de igual manera que la presencia y representación del cuerpo femenino transgrediera espacios públicos antes inimaginables, como fue el caso de los espectáculos erotizados de las actrices de teatro o la venta de tarjetas postales de desnudo femenino. El cambio en los roles de género se hizo presente, pero también la apropiación y el consumo del cuerpo femenino cambió de forma y dinámica.

Una parte del género femenino amenazó la estabilidad moral porque mediante sus espectáculos retaron a las figuras públicas de la política, emitieron opiniones y críticas, a través de un lenguaje que hacía uso de metáforas sexuales para ridiculizar o caricaturizar los temas. De igual manera, tales diversiones ofrecieron al público el acceso visual al cuerpo sin tanto recato; en consecuencia, la moral de este tipo de mujeres se puso en duda constantemente, más aún cuando sus vestuarios eran estrafalarios y en ocasiones diminutos para exaltar su voluptuosidad. 
Muy a pesar de las fuertes calumnias o juicios, muchas actrices alcanzaron un éxito rotundo, como fue el caso de Celia Montalván, quien mereció la masificación de su imagen, sus fotos impresas en tamaño postal se editaron varias veces y se convirtieron en "punto de encuentro de las clases, lujo de pobres, manía de coleccionistas, satisfechos vouyeurs" ${ }^{45}$ Estas imágenes circularon por las calles y se instauraron como un modelo femenino totalmente ajeno a las mujeres "reales"; es por ello que causaban tanta sensación, pues ellas estaban para entretener y seducir las miradas y los tiempos de ocio. De esta manera, las modelos de las postales se convirtieron en objeto de devoción o consumo a través de la fotografía masificada; serán "las divas reverenciables y las mujeres anónimas cuya desnudez trastorna, las vedettes de belleza a la disposición de las frustraciones". ${ }^{46}$

Este aspecto es significativo, pues posiblemente se seleccionaron estos estereotipos negativos porque en el imaginario ya contaban con una connotación transgresora. De esta manera se refuerza también la idea de que aquellas mujeres que trasgreden se hacen deseables en la fantasía sexual, alimentan la fascinación y el gusto por lo prohibido. Este factor se duplica en este tipo de imágenes, primero por la manera en que se representa el cuerpo, y en segunda instancia por la condena moral que llegan a tener en la prensa estos productos comerciales, lo cual generó una opinión pública e incluso una difusión del mercado. A pesar de que el objetivo primordial sea la censura, a través de ella inevitablemente se da propaganda al producto.

Las modelos en su mayoría fueron de complexión media y figura curvilínea, con la cintura bien marcada y la ausencia de vello corporal. Hasta el momento no hay ningún tipo de documentación que nos deje conocer sus historias, por lo cual no hay noción de su procedencia, edad, ni ocupación real. Sin embargo, es posible intuir que no procedían de una clase acomodada o que no desempeñaban un trabajo en el teatro o la danza por dos razones principales: la primera es debido a que el desnudo femenino, por su posicionamiento al límite entre el arte y la obscenidad, representó un

45 Carlos Monsiváis, Escenas de pudor y liviandad, 23, 135.

46 Monsiváis, Escenas de pudor y liviandad, 26, 135. 
riesgo para el prestigio, como ocurrió con el asesinato de Sara Perea, por lo cual es posible descartar que las mujeres de clase acomodada fueran partícipes de estas actividades, sin mencionar que para su posición económica no era imprescindible un empleo; en segunda instancia podemos descartar de igual manera que las modelos formaran parte de los grupos de actrices o bailarinas, ya que las fotografías que se hicieron de ellas siempre hicieron público el nombre de las modelos, pues era una forma de promover su fama y trabajo.

Esta hipótesis se comprobó con imágenes como las de Celia Montalván (fig. 5), donde se muestra parcialmente desnuda de los hombros, mientras el resto de su cuerpo está cubierto por una manta. En la parte superior izquierda aparece su nombre y se constata, de igual manera, que el cuerpo no se expone por completo a la mirada del espectador; por el contrario, se establece únicamente un juego en el cual se sabe que está desnuda bajo la manta, mas nunca se hace explícito.

De esta manera, sólo nos queda pensar en la posibilidad de que quienes aparecen totalmente desnudas en la serie de postales de la CIF fueran modelos temporales pagadas por los artistas, estudiantes de arte y fotografía, o que fueran prostitutas contratadas como modelos, ya que en los documentos referentes a la serie de postales no hay referencias de autores o modelos.

La CIF, si bien dejaba ver su sello en las imágenes, mantuvo en el anonimato a quienes colaboraban en la empresa. En este sentido, otro de los factores que influyeron en este mecanismo tuvo que ver con la compra sobre los derechos de las imágenes; seguramente era más redituable para la compañía obtener todos los derechos sobre la imagen antes que pagar a diversos autores por ellas. Aunado a esto se encuentra también la colaboración de diversas instituciones que de alguna manera justificaron la aparición y circulación de dichas postales.

Este último elemento nos lleva a la recepción y la apertura del contexto histórico para establecer nexos con otras latitudes, ya que las fotografías que 
Nierika 20 - Año 10 - julio-diciembre de 2021

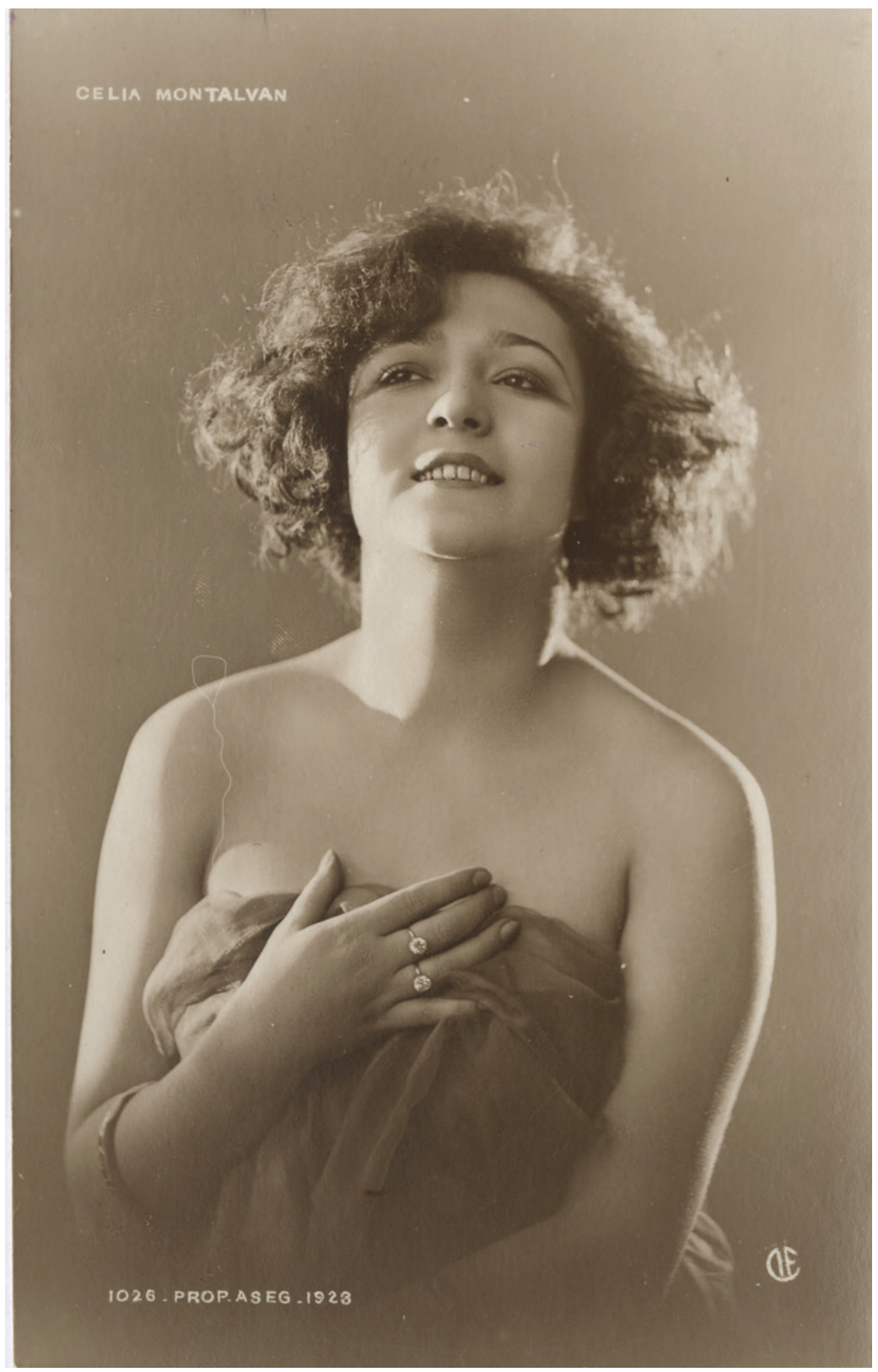

Figura 5. Compañía Industrial Fotográfica, Celia Montalván. Tarjeta postal. Ciudad de México, ca. 1920, Fototeca Manuel Toussaint, Colección Teatro y Still Cinematográfico, Instituto de Investigaciones Estéticas-UNAM. 
realizaba la CIF comparten contenido y forma con las postales que se vendieron en Europa y Estados Unidos, factor que permite ver la generación de imágenes que se debatían entre lo tradicional y lo moderno para dar vida a objetos de consumo innovadores. Estos objetos llaman la atención, porque más allá de los elementos iconográficos que componen la imagen, éstas cuentan con amplia libertad de movimiento y circulación entre la sociedad.

A pesar de poseer un contenido erotizado, éste no denomina al producto como pornográfico, por lo cual no es legislado, a pesar de los debates que se sostuvieron en los periódicos y revistas de la época. ${ }^{47}$ Por lo cual, uno de los intereses de la recepción se preocupó por entender cómo fue posible la circulación en el espacio público de un discurso erótico del cuerpo femenino, que formaba parte de la preocupación de las autoridades, y qué mecanismos permitieron esta libertad de tránsito nacional e internacional. Para ello se atendió al registro de la imagen como propiedad artística y literaria ante la SEP en colaboración con la Escuela Nacional de Artes Plásticas; este trámite se dio a conocer mediante el Diario Oficial de la Federación. A través de él se comprendió el acuerdo institucional que cobija estos desnudos femeninos como obra artística, lo que genera en consecuencia que las instituciones de gobierno no las consideren objetos pornográficos aunque estén sujetos a múltiples interpretaciones, ${ }^{48}$ las cuales no necesariamente aluden al argumento de una alta cultura que entiende de dónde provienen los elementos iconográficos que componen estas fotografías.

En consecuencia, las postales presentan una ambigüedad que se compone, por una parte, por el atractivo erótico que se convierte en un objeto de

47 Distintos periódicos como El Tiempo, El Universal, El Faro y El Nacional Gráfico publicaron entre 1900 y 1930 los debates legales, morales y artísticos en torno a la venta de las fotografías de desnudo femenino. Para un análisis más detallado se puede consultar la tesis de maestría: Aura Mariana Medina Hernández, Fotografía, consumo y el desnudo femenino, 104-124.

48 Se debe acotar que la ley de imprenta publicada en 1917 cuenta con varios huecos conceptuales que posibilitan emplear la legislación de lo socialmente aceptable a la conveniencia del caso, pues términos como: pudor, decencia, buenas costumbres y carácter obsceno, nunca fueron acotados, por lo cual fue posible la defensa de imágenes como las de la CIF o, en caso de defensa del honor masculino, como el asesinato de Sara Perea. 
consumo masivo que no respeta posición social y económica; se vulgarizan así elementos tradicionales de arte para poner en circulación cuerpos femeninos desnudos que ocupan un espacio público y privado. Por otra parte, se institucionaliza su valor artístico, algo que distingue estas postales de cualquier otro producto fotográfico común y corriente y que, a la vez, las excluye del ejercicio de la pornografía.

El procedimiento fue exitoso porque mientras la pornografía de la época, al ser un producto transgresor cuida el anonimato de sus participantes y carece de derechos de autor, las postales eróticas se registran como producción artística y pasan a resguardarse en los lineamientos legales y moralmente aceptables. Se establece de esta manera un juego entre las postales como objetos de deseo y objetos artísticos, pues si bien es cierto que la producción de desnudos de la industria que se estudió utiliza también el anonimato de sus fotógrafos y modelos, esto pierde sentido en cuanto se compran los derechos sobre estas imágenes, pues este simple hecho legaliza el producto.

Con esto no se debe pensar que las postales fueron aceptadas en su totalidad; por el contrario, se establecieron debates interesantes en la prensa que cuestionaron la validez del desnudo en el espacio público, así como su consumo popular. Al final, la preocupación en sí no giró en torno al entendimiento del cuerpo como un objeto del arte, sino a los sujetos que tuvieron acceso a este tipo de representaciones, pues hubo un miedo latente por la forma en que cierta parte de la población leyó y utilizó dichas postales para fines placenteros.

De esta forma se observó que las inquietudes que generaron estas postales rompieron los límites nacionales para insertarse en un ámbito internacional que no sólo expresó la necesidad por controlar la difusión del consumo masivo de este producto, sino que se manifestó una construcción del imaginario colectivo del erotismo, el cual se rastrea mediante las similitudes iconográficas e iconológicas que se ven representadas en estos objetos, como fue el caso del orientalismo y la recreación de espacios mitológicos o clásicos, como escenarios recurrentes en la producción mexicana y europea de postales de desnudos femeninos. 
Y es que no se trata únicamente de los valores morales que están en juego, sino también de una característica propia de la modernidad: la insistencia por vigilar y controlar a los sujetos que componen su sociedad, de reivindicar sus actitudes y acciones, un acto que se lleva a cabo comúnmente para lo que refiere a las pasiones, los instintos, las pulsiones y los deseos, ${ }^{49}$ al menos en este caso muy particular que pelea las líneas tan difusas y problemáticas entre arte y pornografía. La preocupación constante radica entonces en lo que ha dejado de ser privado para ocupar una esfera pública y desinhibida, un producto que ante los ojos de la tradición pone en riesgo los ideales de comportamiento de hombres, mujeres y niños.

En este caso no son las estructuras educativas o gubernamentales las que juzgan negativamente este tipo de postales, sino un fragmento de la propia población la que toma parte en el juicio, una señalización que se extiende a los que producen, consumen y permiten el consumo. En otras palabras, si el poder de señalar negativamente este tipo de productos masivos no se ejerce por parte de las instituciones con incidencia legislativa, hay otros instrumentos que operan esta función. ${ }^{50}$

A lo largo del análisis que se llevó a cabo en los medios impresos para identificar el impacto que tuvieron tales imágenes, destacaron tres reacciones: la primera de ella negó por completo la viabilidad de las representaciones de desnudo femenino, la segunda consideró el cuerpo desnudo como medio artístico, pero enfatizó el cuidado que debía tenerse para quienes lo consumen y lo leen bajo el velo de la obscenidad y el morbo,

49 Michel Foucault, Vigilar y castigar, 27.

50 La idea que me interesa recatar aquí es la manera en que las estructuras de poder generan o producen a los sujetos que le son necesarios. En palabras de Michel Foucault, "[h]ay que admitir, en suma, que este poder se ejerce más que se posee, que no es el 'privilegio' adquirido o conservado de la clase dominante sino el efecto en conjunto de sus posiciones estratégicas, efecto que se manifiesta, y a veces acompaña, la posición de aquellos que son dominados. Este poder, por otra parte, se aplica a quienes 'no lo tienen' pura y simplemente como una obligación o una prohibición; los invade, pasa por ellos y a través de ellos; se apoya sobre ellos, del mismo modo que ellos mismos, en su lucha contra él, se apoyan a su vez en el lugar de presas que ejerce sobre ellos". Foucault, Vigilar y castigar, 36. 
mientras que la tercera vía mostró una falta de precaución por aquellos desnudos denominados artísticos. Frente a esta diversidad de opiniones y críticas sólo es posible identificar la coexistencia de diferentes discursos que presentan formas diversas de una doble moral, la cual evidencia una vez más ese ir y venir entre la tradición y la modernidad.

En suma, el fenómeno de las postales de desnudo femenino artístico se inserta en un proceso más amplio que sobrepasa los límites regionales, para poner en juego la comunicación de modelos tradicionales y modernos en el ámbito internacional. El espacio de acción de estas postales permite entonces la construcción de un imaginario colectivo del erotismo que pone sobre la mesa las mismas preocupaciones en México y al otro lado del Atlántico: el cuestionamiento de quién es apto o no para gozar del contenido del cuerpo femenino erotizado, y más aún, hasta dónde debe permitirse la experiencia del placer sexual a través de la mirada, un problema expresado en la opinión pública que se difunde en México, España e Italia, por poner sólo algunos ejemplos.

\section{Bibliografía}

Bourdan, Christian. Jean Agélou. De l'académisme à la photographie de charme. París: Marval, 2006.

Bourdieu, Pierre. La distinción. Criterio y bases sociales del gusto. Madrid: Taurus, 2012.

Córdova, Carlos. Tríptico de sombras. Ciudad de México: Conaculta, 2012. Fontcuberta, Joan (ed.). Estética fotográfica. Una selección de textos. Barcelona: Gustavo Gili, 2013.

Foucault, Michel. Vigilar y castigar: nacimiento de la prisión, Ciudad de México: Siglo xxı Editores, 2009.

Hammond, Paul. French Undressing: Naughty Postcards from 1900 to 1920. Londres: Jupiter, 1976.

Jesús González, Antonio y Eva María Delgado Sánchez. Postales andaluzas. Rafael Señan y la fotografía turística (1864-1911). Córdoba, España: Caja Sur Publicaciones, 2009. 
Kempe, Jashca. 100 Nudes. A History of Erotic Photography from 18391939. Seúl: Taschen, 2014.

Kossoy, Boris. Lo efímero y lo perpetuo. Madrid: Cátedra, 2014.

Kulka, Tomas. El kitsch. Madrid: Casimiro, 2011.

Lemagny, Jean Claude y André Rouillé. Historia de la fotografía. Barcelona: Ediciones Martínez Roca, 1988.

López Hurtado, Mariana. "La tarjeta postal como documento. Estudio de usuarios y propuesta de un modelo analítico. Aplicación a la colección de postales del Ateneo de Madrid" (tesis doctoral). Madrid: Universidad Complutense de Madrid, 2013.

Manrique, Jorge Alberto. Una visión del arte y de la historia, t. Iv. Ciudad de México: IIIE-UnAm, 2007.

Medina Hernández, Aura Mariana. "Fotografía, consumo y el desnudo femenino: Las tarjetas postales de desnudo femenino de la Compañía Industrial Fotográfica, 1924" (tesis de maestría). Ciudad de México: Centro de Investigación y Docencias Económicas, 2016.

Mélon, Marc. "Más allá de lo real: La fotografía artística". En Jean Claude Lemagny y André Rouillé. Historia de la fotografía. Barcelona: Ediciones Martínez Roca, 1988.

Moles, Abraham. El kitsch. El arte de la felicidad. Barcelona: Paidós, 1990.

Monsiváis, Carlos. Escenas de pudor y liviandad. Ciudad de México: Debolsillo, 2004

Monterrey en 400 fotografías. Monterrey: Museo de Arte Contemporáneo, 1996.

Nead, Lynda. El desnudo femenino: arte, obscenidad y sexualidad. Madrid: Alianza / Tecnos, 2013.

Novo, Salvador. Viajes y Ensayos I. Ciudad de México: FCE, 1996.

Osorio Olave, Alejandra y Felipe Victoriano Serrano. Postales del Centenario. Imágenes para pensar el Porfiriato. Ciudad de México: UAm, 2009.

Palá Laguna, Francisco. "La tarjeta postal ilustrada". En Los sitios de Zaragoza en la tarjeta postal ilustrada. Madrid: Fundación Zaragoza, 2008.

Reyes, Aurelio de los. "Crimen y castigo: la disfunción social en el México posrevolucionario". En Historia de la vida cotidiana en México, t. 5, vol. 2. Ciudad de México: FCE, 2008. 
Rubenstein, Anne. "La guerra contra las 'las pelonas' las mujeres modernas y sus enemigos, Ciudad de México, 1924". En Género, poder y política en el México posrevolucionario. Ciudad de México: FCE, 2009.

Vargas, Ava. La casa de citas en el barrio galante. Ciudad de México: Camera Lucida / Conaculta, 1991.

Wijnekus, F. J. M. y E. F. PH Wijnekus. Dictionary of the printing and Allied Industries: in English, French, German, Dutch, Spanish and Italian. Ámsterdam: Elsevier, 2013.

Zubiaurre, Maite. Culturas del erotismo en España 1898-1939. Madrid: Cátedra, 2014.

\section{Hemerografía}

Diario Oficial de la Federación, 14 de julio de 1922, t. xxI, número 63. Hemeroteca del AGN.

El Correo Español, 31 de diciembre de 1902, 3.

"Producción artística y literaria", caja 327, exp. 3797 y caja 474, exp. 6257. AGN. Secretaría de Comercio y Fomento Industrial, Patentes y Marcas, leg. 196, exp. 23 у exp. 71 .

\section{Aura Mariana Medina Hernández}

Licenciada en Historia con especialización en Historia de Arte por parte de la UNAM. En el 2015 realizó sus estudios de maestría en Historia Internacional en el CIDE, programa que le permitió realizar una estancia de investigación en el Instituto Universitario de Estudios de la Mujer de la Universidad Nacional Autónoma de Madrid. Desde el 2017 ha impartido clases a nivel medio superior y superior en la Universidad para el Desarrollo Empresarial y Pedagógico. Se ha desempeñado también como fotógrafa en el cortometraje de literatura infantil de la revista Tierra Adentro de Conaculta, así como investigadora iconográfica en el cortometraje "No son las bicicletas" (Tierra Adentro-Conaculta) y en el programa Juicios de México "Proceso contra Filomeno Bravo" que llevó a cabo el Canal Judicial. 